Original Article

\title{
EVALUATION OF ANTIHYPERLIPIDEMIC, ANTI-INFLAMMATORY, AND ANALGESIC ACTIVITIES OF EURYCOMA LONGIFOLIA IN ANIMAL MODELS
}

\author{
PHEBE HENDRA*, FENTY, PUTU RIRIN ANDREANI, BERNADETHA MARIA ESTIKA PANGESTUTI, \\ JEFFRY JULIANUS
}

Faculty of Pharmacy, Sanata Dharma University, Paingan, Maguwoharjo, Depok, Sleman, Yogyakarta 55282, Indonesia

Email: phebe_hendra@usd.ac.id

Received: 21 Nov 2016 Revised and Accepted: 17 Jan 2017

\begin{abstract}
Objective: To investigate the anti-hyperlipidemic, anti-inflammatory and analgesic properties of of E. longifolia root extract in animal models.

Methods: In this study, glucose-fructose enriched diet-induced hyperlipidemia, carrageenan-induced paw edema and acetic acid-induced writhing were used to evaluate the anti-hypertriglyceridemia, anti-inflammatory and analgesic activities, respectively. At the end of the experiment of glucose-fructose enriched diet-induced hyperlipidemia, blood samples were collected and estimation of blood lipids were carried out. Edema thickness was measured using digital caliper at $0,15,30,45,60,90,120,150,180,210,240,270,300,330$, and 360 min after carrageenan injection. The number of abdominal writhing for each mouse was observed and counted during a period of $1 \mathrm{~h}$ post injection of acetic acid.
\end{abstract}

Results: E. longifolia root extract demonstrated a significant reduction of triglyceride levels $(p<0.05)$ compared with the control group in glucosefructose enrich diet in rats. In anti-inflammatory test, the extract significantly inhibited the carrageenan induced paw edema formation $(p<0.05)$. The extract also significantly decreased the number of writhing in acetic acid-induced mice $(p<0.05)$.

Conclusion: E. longifolia root extract shown a significant anti-hypertriglyceridemia, anti-inflammatory and analgesic activities. Further studies are needed to determine mechanisms for its acitivities of E. longifolia root extract.

Keywords: Eurycoma longifolia, Antihypertriglyceridemia, Anti-inflammatory, Analgesic

(C) 2016 The Authors. Published by Innovare Academic Sciences Pvt Ltd. This is an open access article under the CC BY license (http://creativecommons.org/licenses/by/4.0/) DOI: http://dx.doi.org/10.22159/ijpps.2017v9i3.16366

\section{INTRODUCTION}

Obesity and the metabolic syndrome continue to plague the world at an alarming rate. Those will cause both substantial socio-economic and physical burden in society. WHO reported that in 2014, over 1.9 billion adults were estimated to be overweight and more than 600 million obese [1]

Recently people have been using natural products and plant to treat a wide variety of clinical disease. One of the most popular traditional plants Eurycoma longifolia Jack (Simaroubaceae) is a well-known folklore herbal medication in Southeast Asia. Wide spectrum of pharmacological activities of E. longifolia has been reported [2-5] Despite wide range of traditional uses known, it is most solely for its aphrodisiac and anti-malarial properties [5-7]. Previous research shows that extracts from the roots of E. longifolia suppressed intracellular lipid accumulation in 3T3-L1 adipocytes, a treatment target for an anti-obesity agent [8]. Based on the previous study and traditional use, the present investigation was carried out to evaluate the antihyperlipidemic, anti-inflammatory and analgesic activities of E. longifolia root extract in animal models.

\section{MATERIALS AND METHODS}

\section{Plant material and chemicals}

E. longifolia was supplied by Merapi Farma Herbal Co. (Batch No. SL.1A.2015. PB; Yogyakarta, Indonesia) and were collected from Kalimantan Island Indonesia. The voucher specimen was deposited at the Laboratory of Pharmaceutical Biology, Faculty of Pharmacy Sanata Dharma University in Yogyakarta Indonesia. The following chemicals were used: sodium carboxy methyl cellulose/CMC-Na (Brataco Chemika, Indonesia); glucose, fructose, methanol and acetic acid (E. Merck, Darmstadt Germany; and carrageenan (Sigma Chemical Company). Diagnostic kit for the estimation of Cholesterol, highdensity lipoprotein cholesterol (HDL-c), low-density lipoprotein cholesterol (LDL-c), triglyceride (TG) kits were purchased were from Roche Diagnostics GmbH, Mannheim, Germany. All other chemical were of analytical grade and were purchased from E. Merck,
Darmstadt, Germany. Instruments used in this study included Cobas C501 (Roche Diagnostics) for serum chemistry analysis.

\section{Preparation of E. longifolia root extract}

The root of E. longifolia were powdered and extracted with 95\% $(\mathrm{v} / \mathrm{v})$ methanol for $48 \mathrm{~h}$ at room temperature. The methanol extract was then distilled, evaporated to obtain semisolid E. longifolia root extract (EL) (yield 9.32\%) and re-dissolved in CMC-Na (1\% w/v).

\section{Test animals and housing}

28 adult male Wistar rats (150-250 g), and 25 adult male and 25 female Swiss mice (20-30 g) were obtained from the Imono Laboratory, Sanata Dharma University, Indonesia. The animals were maintained under standard laboratory condition. They were housed in standard cages (five animals per cage) at temperature $22^{\circ} \pm 2{ }^{\circ} \mathrm{C}$ and 12:12h light dark cycle. The animals were provided with pelleted diet as normal diet or glucose-fructose enriched diet (GFED) and water ad libitium. All procedures described were reviewed and approved with approval number KE/KF/337/EC by Medical and Health Research Ethics Committee Faculty of Medicine Gadjah Mada University Yogyakarta Indonesia.

\section{Antihyperlipidemic study}

Healthy male rats were fasted overnight and randomly divided into four groups each containing 7 animals. The control group was fed normal diet until the end of treatment. The remaining groups were fed GFED for 42 d [9]. Following confirmation of GFED-induced hypertriglyceridemia, the three groups were then divided into group I (EL $75 \mathrm{mg} / \mathrm{kg} \mathrm{b} / \mathrm{w}$ ), group II (EL $150 \mathrm{mg} / \mathrm{kg} \mathrm{b} / \mathrm{w}$ ) [10], and group GFED-control (continued with vehicle). All treatments were continued for $5 \mathrm{~d}$ following oral administration. At the end of treatment, rats in all groups were anaesthetized with ketamine. The blood was collected from all groups of rats by retro-orbital sampling for serum chemistry analysis. Serum lipid profile tests were measured using commercial kits (Roche Diagnostics) 


\section{Anti-inflammatory study}

Male Swiss mice were divided into five groups randomly (negative control, positive control and dose groups), consisting of 5 mice in each group. Acute edema was induced by the injection of carrageenan1\% (prepared in normal saline) into the sub-plantar region of hind-paw of mice [11]. Then, each group was treated orally with $1 \%$ CMC-Na (negative control), $4.48 \mathrm{mg} / \mathrm{kg}$ BW of diclofenac sodium (positive control), and treatment doses of 105, 210 and 420 $\mathrm{mg} / \mathrm{kg}$ BW EL [10]. Edema thickness was measured using digital caliper at $0,15,30,45,60,90,120,150,180,210,240,270,300,330$, and $360 \mathrm{~min}$ after carrageenan injection $[12,13]$. The calculation of the edema volume was conducted using formula area under curve (AUC) and percentage of inhibition of inflammation [13-15].

Area under curve (AUC) was calculated for each minute within 0-6 h using trapezoid method formula, as below:

$$
\mathrm{AUC}_{\mathrm{tn}-1}^{\mathrm{tn}}=\frac{\mathrm{T}_{\mathrm{tn}-1}+\mathrm{T}_{\mathrm{tn}}}{2}\left(\mathrm{t}_{\mathrm{n}}-\mathrm{t}_{\mathrm{n}-1}\right)
$$

$\mathrm{T}_{\mathrm{tn}-1}$ : Average edema volume on $\mathrm{t}_{\mathrm{n}-1}$

$\mathrm{T}_{\mathrm{t}}$ : Average edema volume on $\mathrm{t}_{\mathrm{n}}$

\section{Analgesic study}

The analgesic activity of EL was tested using acetic acid-induced writhing method $[11,14,15,17]$. Female mice Swiss were divided randomly into five groups $(\mathrm{n}=5)$. Group I as negative control received 1\% CMC-Na, group II as positive control received $91 \mathrm{mg} / \mathrm{kg}$ BW of aspirin, group III-V received 105, 210 and $420 \mathrm{mg} / \mathrm{kg}$ BW of EL respectively. After 5 min of treatment, all animals were administered $1 \%$ with $50 \mathrm{mg} / \mathrm{kg} \mathrm{BW}$ of acetic acid intraperitoneally. The total number of writhes was recorded at intervals of $5 \mathrm{~min}$ for a period of $1 \mathrm{~h}$. The calculation of percentage of inhibition using the following ratio: (control mean-treated mean)/control mean x $100[14,15]$.

\section{Statistical analysis}

Results are expressed as mean \pm standard deviation (SD). Data were analyzed using one-way analysis of variance followed by post-hoc Tukey HSD tests using SPSS 22. A $p$-value $<0.05$ was considered statistically significant. Statistical differences were determined using the Student's $t$-test, with $p$-values being indicated for each fig.

\section{RESULTS}

Effect of E. longifolia root extract in hyperlipidemia-induced rats

The administration of GFED significantly increased $(p<0.05)$ TG levels up to $186.1 \%$ and decreased high-density lipoprotein (HDL) levels by $43.0 \%$ (table 1 ). GFED did not increase serum total cholesterol or low-density lipoprotein (LDL) levels.

Daily administration of both doses of EL for $5 \mathrm{~d}$ led to a significant reduction $(p<0.05)$ in TG compared with the GFED group. There was no significant difference in HDL levels among all doses of EL and those of the GFED group.

Table 1: Effect of E. longifolia root extract on lipid parameters in rats feeds with glucose-fructose enrich diet (GFED)

\begin{tabular}{|c|c|c|c|c|}
\hline Treatment & Cholesterol (mmol/l) & Triglyceride (mmol/l) & HDL-c (mmol/l) & LDL-c (mmol/l) \\
\hline Normal diet & $1.74 \pm 0.16$ & $1.08 \pm 0.09 \mathrm{~b}$ & $1.65 \pm 0.08^{\mathrm{b}}$ & $0.21 \pm 0.05$ \\
\hline GFED & $1.86 \pm 0.15$ & $3.08 \pm 0.21^{\mathrm{a}}$ & $0.94 \pm 0.07^{a}$ & $0.24 \pm 0.04$ \\
\hline GFED+EL 75 mg/kgBW & $1.69 \pm 0.26$ & $2.69 \pm 0.34 \mathrm{a}, \mathrm{b}$ & $0.92 \pm 0.07^{a}$ & $0.25 \pm 0.06$ \\
\hline GFED+EL $150 \mathrm{mg} / \mathrm{kgBW}$ & $1.88 \pm 0.17$ & $0.43 \pm 0.05^{\mathrm{a}, \mathrm{b}}$ & $0.70 \pm 0.08^{\mathrm{a}, \mathrm{b}}$ & $0.37 \pm 0.07$ a,b \\
\hline
\end{tabular}

Values are expressed as mean $\pm \mathrm{SD}$ of seven animals in each group; a: $p<0.05$ vs normal diet; $\mathrm{b}: p<0.05$ vs GFED

\section{Effect of E. longifolia root extract on carrageenan-induced mice}

The anti-inflammatory activity of E. longifolia root extract against carrageenan induced paw edema showed that the extracts exhibit significantly $(p<0.05)$ and dose-dependently reduced the paw edema swelling (table 2). The percentage inhibition in the paw edema in mice treated with E. longifolia root extract was found to be 15.7; 22.0 and $26.8 \%$ at the dose of $105 ; 210$ and $420 \mathrm{mg} / \mathrm{kg}$ BW respectively.

Table 2: Effect of E. longifolia root extract on carrageenan-induced mice

\begin{tabular}{lll}
\hline Treatment & AUC & \% inhibition \\
\hline Negative control (CMC Na) & $426.7 \pm 18.3^{\mathrm{b}}$ & 0.0 \\
Positive control (diclofenac sodium 4.48 mg/kg BW) & $255.9 \pm 16.8^{\mathrm{a}}$ & 40.0 \\
EL $105 \mathrm{mg} / \mathrm{kg} \mathrm{BW}$ & $359.6 \pm 5.8^{\mathrm{a}, \mathrm{b}}$ & 15.7 \\
EL $210 \mathrm{mg} / \mathrm{kg} \mathrm{BW}$ & $333.0 \pm 5.6^{\mathrm{a}, \mathrm{b}}$ & 22.0 \\
EL $420 \mathrm{mg} / \mathrm{kg} \mathrm{BW}$ & $312.4 \pm 4.0^{\mathrm{a}, \mathrm{b}}$ & 26.8 \\
\hline
\end{tabular}

Values are expressed as mean $\pm \mathrm{SD}$ of five animals in each group; $\mathrm{a}$ : $p<0.05$ vs negative control; $\mathrm{b}$ : $p<0.05$ vs positive control

Effect of E. longifolia root extract on acetic acid-induced writhing in mice

Table 3 showed the effect of $E$. longifolia root extract on acetic acidinduced writhing in mice. All of the doses of E. longifolia root extract produced significant $(p<0.05)$ reduction of writhing by the acetic acid in a dose dependent manner.

The percent inhibition of 105,210 and $420 \mathrm{mg} / \mathrm{kg}$ BW was 25.4 ; 57.3 and $59.0 \%$ for E. longifolia root extract respectively.

Table 3: Effect of $E$. longifolia root extract on acetic acid induced writhing in mice

\begin{tabular}{lll}
\hline Treatment & Number of writhing & \% inhibition \\
\hline Negative control (CMC Na) & $57.6 \pm 1.1^{\mathrm{b}}$ & 0.0 \\
Positive control (aspirin 91 mg/kgBW) & $16.2 \pm 1.3^{\mathrm{a}}$ & 71.9 \\
EL $105 \mathrm{mg} / \mathrm{kg} \mathrm{BW}$ & $43.0 \pm 1.0^{\mathrm{a}, \mathrm{b}}$ & 25.4 \\
EL $210 \mathrm{mg} / \mathrm{kg} \mathrm{BW}$ & $24.6 \pm 2.1^{\mathrm{a}, \mathrm{b}}$ & 57.3 \\
EL $420 \mathrm{mg} / \mathrm{kg} \mathrm{BW}$ & $23.6 \pm 4.2^{\mathrm{a}, \mathrm{b}}$ & 59.0 \\
\hline
\end{tabular}

Values are expressed as mean \pm SD of five animals in each group; a: $p<0.05$ vs negative control; b: $p<0.05$ vs positive control 


\section{DISCUSSION}

Several studies have reported that a high carbohydrate diet is responsible for the development of hypertriglyceridemia in rodent animal models $[9,18-20]$. Hypertriglyceridemia occurs because high fructose in the blood leads to increased de novo hepatic fatty acid synthesis and, subsequently, this releases a high amount of TG [21]. The E. longifolia root extract used in our study reduced TG levels induced by glucose-fructose enrich diet. Therefore, the E. longifolia root extract has a potent anti-hypertriglyceridemia activity in rats. These reductions of TG may be associated with a previous in vitro report in which E. longifolia suppressed lipid accumulation in 3T3-L1 adipocytes [8].

Carrageenan, as irritant substances, induced inflammation in biphasic event. The initial phase is associated to the release of serotonin, histamine, and bradykinin; while the late phase is attibuted to the release of prostaglandin and induce of cyclooxygenase that increasing vascular permeability and the neutrophil infiltration into the inflammatory site and production of free radicals that cause edema [22]. In our results, the E. longifolia root extract significantly inhibited paw edema-induced carrageenan in all the dose level.

Additionally, the E. longifolia root extract showed significant analgesic action at all dose levels (105, 201 and $420 \mathrm{mg} / \mathrm{kg} \mathrm{BW})$. Analgesic effect was evaluated using acetic acid-induced writhing test in mice. Acetic acid injection has been associated with increased level of $\mathrm{E}$ and $\mathrm{F}$ prostaglandins in peritoneal fluids as well as lipoxygenase products [23]. The significant reduction of E. longifolia root extract might be due to the presence of analgesic principles acting with the prostaglandin pathways.

It has been reported that E. longifolia contains quassinoids, triterpene, biphenylneolignan and alkaloid [7, 24-26]. The presence of eurycomaloactone, 14,15 $\beta$-dihydroklaieanone and 13, 21dehydroeurycomanone in E. longifolia root were identified as potent NF- $\kappa B$ inhibitors $[27,28]$. They act by inactivation of the NF- $\kappa B$ signaling pathway, a pro-inflammatory transcriptional factor. Therefore, their inhibition results in anti-inflammatory effect. Antiinflammatory and analgesic effects of E. longifolia root extract in this study are in agreement with a previous study. Han et al. demonstrated that methanolic extract of E. longifolia root has a potential analgesic agent on both heat-induced pain and chemical induced pain in hot plate test and acetic acid-induced writhing test, repectively. Methanolic extract of $E$. longifolia root also has antiinflammatory agent on carrageenan-induced paw edema [10].

\section{CONCLUSION}

In conclusion, we can confirm that E. longifolia root extract are endowed with anti-hypertriglyceridemic, anti-inflammatory and analgesic properties that support to the traditional use of this plant. However, further study is needed to investigate the mechanisms of pharmacological effects.

\section{CONFLICTS OF INTERESTS}

The authors declare that they have no conflicts of interest

\section{REFERENCES}

1. WHO. Obesity and Overweight; 2015. Available from: http://www.who.int/mediacentre/factsheets/fs311/en/. [Last accessed on 20 Oct 2016]

2. Mohamed AN, Vejayan J, Yusoff MM. Review on Eurycoma longifolia pharmacological and phytochemical properties. J Appl Sci 2015;15:831-44.

3. Al-Salahi OSA, Lam CK, Majid AMSA, Al-Suede FSRA, Saghir SAM, Abdullah WZ, et al. Anti-angiogenic quassinoid-rich fraction from Eurycoma longifolia modulates endothelial cell function. Microvasc Res 2013;90:30-9.

4. Jiwajinda S, Santisopasri V, Murakami A, Sugiyama H, Gasquet $\mathrm{M}$, Riad $\mathrm{E}$, et al. In vitro anti-tumor promoting and antiparasitic activities of the quassinoids from Eurycoma longifolia, a medicinal plant in Southeast Asia. J Ethnopharmacol 2002;82:55-8.

5. Rashid M, Kumar S, Ahmad B. Medical uses of Eurycoma longifolia Jack: a review. Pharm Res 2009;2:70-8.
6. Chan KL, Choo CY, Abdullah NR, Ismail Z. Antiplasmodial studies of Eurycoma longifolia jack using the lactate dehydrogenase assay of Plasmodium falciparum. J Ethnopharmacol 2004;92:223-7.

7. Chua LS, Amaiza N, Amin M, Chun J, Neo H, Lee TH, et al. LCMS/MS-based metabolites of Eurycoma longifolia (Tongkat Ali) in Malaysia (Perak and Pahang). J Chromatogr B: Anal Technol Biomed Life Sci 2011;879:3909-19.

8. Lahrita L, Kato E, Kawabata J. Uncovering potential of indonesian medicinal plants for glucose uptake enhancement and lipid suppression against 3T3-L1 adipocytes. J Ethnopharmacol 2015;168:229-36.

9. Hendra P, Jamil OA, Maharani DA, Suhadi MA, Putri CY, Fenty, et al. Antihyperlipidemic and hepatoprotective studies on leaves of Macaranga tanarius. Asian J Pharm Clin Res 2017;10:1-3.

10. Han YM, Woo SU, Choi MS, Park YN, Kim SH, Yim H, et al. Antiinflammatory and analgesic effects of Eurycoma longifolia extracts. Arch Pharm Res 2016;39:421-8.

11. Chamundeeswari D, Vasantha J, Gopalakrishnan S, Sukumar E. Anti-inflammatory and antinociceptive activities of Trewia polycarpa roots. Fitoterapia 2004;75:740-4.

12. Belemkar S, Thakre SA, Pata MK. Evaluation of anti-inflammatory and analgesic activities of methanolic extract of Adhatoda vasica nees and Mentha piperita Linn. Inventi J 2013;2:1-6.

13. Boakye-Gyasi E, Woode E, Ainooson GK, Obiri DD, Ansah C, Duwejua M, et al. Anti-inflammatory and antipyretic effects of ethanolic extract of Palisota hirsuta K. schum roots. Afr J Pharm Pharmacol 2008;2:191-9.

14. Nguemfo EL, Dimo T, Azebaze AGB, Asongalem EA, Alaoui K, Dongmo $\mathrm{AB}$, et al. Anti-inflammatory and anti-nociceptive activities of the stem bark extract from allanblackia monticola STANER L. C. (Guttiferae). J Ethnopharmacol 2007;114:417-24.

15. Chaulya NC, Haldar PK, Mukherjee A. Anti-inflammatory and analgesic activity of methanol extracts of Cyperus tegetum Roxb. Rhizome. J PharmaSciTech 2012;1:27-9.

16. Sinatra RS, Jahr JS, Watkins-Pitchford JM. editors. The Essence of Analgesia and Analgesics. London: Cambridge University Press; 2011.

17. Rahayu L, Dewi RS, Ayu G. Anti-inflammation and analgesic test effect of senggani leaves (Melastoma malabathricum L.) infusion. Indonesian J Pharm Sci 2016;14: 93-8.

18. Huang IS, Ho H, Hoffman BB, Reaven GM. Fructose-induced insulin resistance and hypertension in rats. Hypertension 1987;10:512-6.

19. Padiya R, Khatua TN, Bagul PK, Kucha M, Banerjee SK. Garlic improves insulin sensitivity and associated metabolic syndromes in fructose fed rats. Nutr Metab 2011;8:53.

20. Tandrasasmita OM, Wulan DD, Nailufar F, Sinambela J, Tjandrawinata RR. Glucose-lowering effect of DLBS3233 is mediated through phosphorylation of tyrosine and upregulation of PPAR $\gamma$ and GLUT4 expression. Int J Gen Med 2011;4:345-7.

21. Huang D, Dhawan T, Young S, Yong WH, Boros LG, Heaney AP. Fructose impairs glucose-induced hepatic triglyceride synthesis. Lipid Health Disease 2011;10;1-10.

22. Necas J, Bartosikova L. Carrageenan: a review. Vet Med 2013;58:187-205.

23. Deraedt R, Jouquey S, Delevallee F, Flahaut M. Release of prostaglandins e dan $\mathrm{f}$ in an algogenic reaction and its inhibition. Eur J Pharmacol 1980;61:17-24.

24. Ang HH, Hitotsuyanagi $\mathrm{Y}$, Fukuya H, Takeya K. Quassinoids from Eurycoma longifolia. Phytochemistry 2002;59:833-7.

25. Huyen LT, Nhiem NX, Thu VK, Tai BH, Anh HLT, Yem PH, et al. Quassinoids from Eurycoma longifolia. Vietnam J Chem 2015;53:82-5.

26. Park S, Nhiem NX, Kiem PV, Minh CV, Tai BH, Kim N, et al. Five new quassinoids and cytotoxic constituents from the roots of Eurycoma longifolia. Bioorg Med Chem Lett 2014;24:3835-40.

27. Hajjouli S, Chateauvieux S, Teiten MH, Orlikova B, Schumacher $\mathrm{M}$, Dicato $\mathrm{M}$, et al. Eurycomanone and eurycomanol from 
Eurycoma longifolia jack as regulators of signaling pathways involves in proliferation, cell death and inflammation. Molecules 2014;19:14649-66.

28. Tran TVA, Malainer C, Schwaiger S, Atanasov AG, Heiss EH, Dirsch VM, et al. NF-kB inhibitors from Eurycoma longifolia. J Nat Prod 2014;77:483-8.

\section{How to cite this article}

- $\quad$ Phebe Hendra, Fenty, Putu Ririn Andreani, Bernadetha Maria Estika Pangestuti, Jeffry Julianus. Evaluation of anti-hyperlipidemic, anti-inflammatory, and analgesic activities of Eurycoma longifolia in animal models. Int J Pharm Pharm Sci 2017;9(3):166-169. 